\section{'Galaxy' Peento Peach}

\section{David W. Ramming ${ }^{1}$}

San Joaquin Valley Agricultural Sciences Center, Agricultural Research Service, United States Department of Agriculture, 9611 South Riverbend Avenue, Parlier, CA 93648

\section{Additional index words. Prunus persica, fruit breeding, cultivar, variety}

Abstract. 'Galaxy' is being released by United States Department of Agriculture, Agriculture Research Service to provide a fresh market, mid-season peento shaped peach that is larger, firmer and more attractive than 'Stark Saturn'. It ripens in late June in the Parlier area of the San Joaquin Valley of California. It has white flesh that is low-acid, sweet, melting and clingstone.

Received for publication 4 Mar. 2005. Accepted for publication 28 May 2005. The author thanks Joe Goffreda for providing pollen ofD33-1-86227 breeding line. Evaluation supported in part by California Tree Fruit Agreement and University of California Kearney Agricultural Center.

${ }^{1}$ Corresponding author; to whom reprint requests should be addressed; e-mail dramming@fresno. ars.usda.gov.

\section{Origin}

'Galaxy' peach [Prunus persica (L.) Barstch] originated in the Fruit Breeding Program of the Crop Diseases, Pests and Genetics Unit of the San Joaquin Valley Agricultural Sciences Center, located at Parlier, Calif. The cross was made in 1994 with pollen from D331-86227 on a tree of P34-106. D33-1-86227 is a white peento peach heterozygous for yellow flesh and nectarine with a complex parentage, developed by Shawn Mehlenbacher and Joe Goffreda, Rutgers University, New Brunswick, New Jersey. P34-106 = [P51-138 open pollinated $=\{$ 'Armking' $\times$ P59-94 $=($ 'Firebrite' $\times$ 'Sunfre') $\}$ ] is a yellow flesh USDA nectarine selection. A population of 114 seedlings were developed by embryo culture procedures from this cross.

The seedlings were planted in the fruiting nursery at Parlier in 1995. 'Galaxy' was selected as Y142-130 in 1997 for its peento shape, large fruit size, good productivity, sweet, low acid flesh and attractive appearance. Following selection, it was propagated asexually by budding onto 'Nemaguard' rootstock and test plantings were established at University of California Kearney Agricultural Center(KAC) and San Joaquin Valley Agricultural Sciences Center (SJVASC), both in Parlier, Calif.

\section{Description}

Fruit characteristics and tree data of 'Galaxy' were obtained from trees growing in two tree plots in research orchards at KAC and SJVASC, Parlier [lat. 36 35'39"N and long. $\left.119^{\circ} 30^{\prime} 41^{\prime \prime} \mathrm{W}\right]$. Trees were trained to an open center form with four scaffold branches. Cultural practices and nutrients were applied to the entire orchard according to standard procedures used in Fresno County, Calif. Irrigation was by flood method applied weekly to every other row. Complete trees were harvested to determine yield and fruit number. Fruit size of the total crop was determined by an optical fruit grader. A 30-fruit sample was taken to determine fruit firmness (measured with a Magness pressure testor and 7.9-mm tip, D. Baullauf Mfg. Co. Inc., Washington, D.C.) and $\%$ soluble solids. Full bloom dates were determined as the time when $90 \%$ of the flowers were open. Field observations included the recording of full bloom date, harvest date and fruit ratings (conducted by D.W.R.) were taken for size, shape, firmness, skin blush and appearance, and taste. The rating scale of 1 to 9 with $9=$ the highest possible and therefore the most desirable rating for the traits, with the exception of crop in which 9 is over cropped, was used. A rating of $5=$ full commercial crop to $7=$ heavy commercial crop would be preferable.

'Galaxy' ripens in the third to fourth week of June, with 'Stark Saturn' peach (Mehlenbacher et al., 1985). 'Stark Saturn' is the recognized and registered trade name of 'N.J. F-2' (Bailey and Hough, 1983). 'Galaxy' fruit $(\mathrm{n}=10)$ averaged $37.8 \mathrm{~N}$ firmness and $14.4 \%$ soluble solids while 'Stark Saturn' averaged 35.4 N firmness and $13.3 \%$ soluble solids on the first pick for both cultivars on June 20, 2002. 'Galaxy' has consistently produced larger fruit than 'Stark Saturn' (Table 1). Most 'Stark Saturn' fruit over 3 years averaged $<7.3 \mathrm{~cm}$ in diameter while 'Galaxy' averaged $>7.3 \mathrm{~cm}$ in diameter and peaked at sizes $>7.6 \mathrm{~cm}$ in 2001 and 2002 . When fruit weight was determined from a 200 fruit sample in 2000, 'Galaxy' averaged $140.5 \mathrm{~g}$ and 'Stark Saturn' averaged $81.3 \mathrm{~g}$. The commercial packout from 22 'Galaxy' trees in their third leaf was 175 single-layer flats $(5 \mathrm{~kg})$ with $41 \%$ of the packout size 21 fruit per box and $31.4 \%$ size $17 / 18$ fruit per box. The peento shaped fruit is round with a slight suture bulge that is less pronounced than 'Stark Saturn'. The tip has very few cracks. At shipping maturity, there are very few pedicle tears, but they start to occur when over-ripe fruit is picked. The flesh is white with red only on the surface of the pit and is low acid in taste. The flesh clings to the pit and is melting in character. The flesh does not brown readily and overall is firmer than 'Stark Saturn'. 'Galaxy' consistently develops more red blush, and is more attractive, firmer and better tasting than 'Stark Saturn' as determined by subjective observations (Table 2).

'Galaxy'flowers have nonshowy petals and are self-fertile. Full bloom dates for 'Galaxy' varied from 20 Feb. to 1 Mar. over 3 years. This is 7 to $15 \mathrm{~d}$ after 'Mayglo' nectarine (Okie 1998), with 'Crimson Baby' nectarine (Okie 1998), 2 to 3 d before 'Mayfire' nectarine (Okie 1998) and 5 to $8 \mathrm{~d}$ before 'Springcrest' peach (Okie 1998). 'Mayfire' is reported to require about 650 hours chilling at $7{ }^{\circ} \mathrm{C}$ (Ramming and Tanner, 1987). Trees of 'Galaxy' are vigorous and productive. They set as much fruit as 'Stark Saturn'. Leaf glands are round. Reaction to bacterial spot is unknown as it does not commonly occur in the San Joaquin Valley of California.

Table 1. Yield and fruit size distribution by percent for 'Stark Saturn' and 'Galaxy'.

\begin{tabular}{|c|c|c|c|c|c|c|c|c|c|}
\hline \multirow[b]{2}{*}{ Name } & \multirow{2}{*}{$\begin{array}{c}\text { Year } \\
\text { planted }\end{array}$} & \multirow{2}{*}{$\begin{array}{c}\text { Total } \\
\text { wt }(\mathrm{kg})\end{array}$} & \multirow{2}{*}{$\begin{array}{c}\text { Total } \\
\text { fruit (no.) }\end{array}$} & \multicolumn{6}{|c|}{ Percent of fruit by fruit diam $(\mathrm{cm})$} \\
\hline & & & & $<7.3$ & $7.3-7.6$ & $>7.6-8.3$ & $>8.3-8.9$ & $>8.9-9.5$ & $<9.5$ \\
\hline Saturn & 1994 & 65 & 804 & 96.7 & 3.2 & 0.1 & & & \\
\hline \multicolumn{10}{|l|}{$2001^{x}$} \\
\hline Saturn & 1994 & 36 & 405 & 74.5 & 33.5 & 3.0 & & & \\
\hline Galaxy $(K)^{y}$ & 1997 & 58 & 305 & 1.2 & 30.3 & 50.9 & 14.6 & 3.0 & \\
\hline Saturn & 1994 & 37 & 354 & 76.3 & 16.1 & 6.5 & 1.1 & & \\
\hline Galaxy $(K)^{y}$ & 1997 & 62 & 377 & 7.2 & 4.2 & 22.3 & 4.5 & 56.0 & 5.8 \\
\hline Galaxy (U) & 1997 & 68 & 460 & 11.7 & 12.8 & 34.8 & 3.2 & 35.0 & 2.0 \\
\hline
\end{tabular}

${ }^{\mathrm{z}}$ Harvested 6/19 and 6/21; $n=2$ trees.

${ }^{y} \mathrm{~K}=$ University of California Kearney Agricultural Center. U = USDA-ARS San Joaquin Valley Agricultural Sciences Center. ${ }^{x}$ Harvested 6/26; $\mathrm{n}=1$ tree.

wHarvested $6 / 20$ and $24 ; n=2$ trees. 
Table 2. Subjective fruit characteristics of 'Galaxy' compared to 'Stark Saturn' at Parlier, Calif. (1997-2003).

\begin{tabular}{lrr}
\hline & \multicolumn{2}{c}{ Cultivar } \\
\cline { 2 - 3 } Characteristic & Galaxy & Saturn \\
\hline Crop $^{\mathrm{z}}$ & 7.4 & 6.7 \\
Size $^{\mathrm{y}}$ & 83.8 & 66.0 \\
Shape $^{\mathrm{x}}$ & 6.6 & 6.1 \\
Firmness $^{\mathrm{x}}$ & 6.8 & 5.7 \\
Blush $^{\mathrm{w}}$ & 5.6 & 3.9 \\
Appearance $^{\mathrm{x}}$ & 6.8 & 4.4 \\
Taste $^{\mathrm{x}}$ & 6.4 & 5.7 \\
\hline
\end{tabular}

${ }^{\mathrm{z}}$ Crop rating 0 to $9,0=$ no crop, $5=$ full commercial crop, $7=$ heavy commercial crop, $9=$ over cropped.

${ }^{y}$ Diameter of fruit in $\mathrm{mm}$. Measurements done under field conditions.

${ }^{x}$ Rating scale 1 to $9 ; 3=$ poor, $5=$ average, $7=$ good, 9 = very good for commercial use.

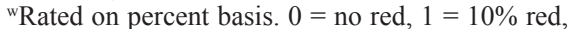
$9=>90 \%$ red.

\section{Availability}

'Galaxy' was indexed by NRSP5 Virus-Tested Fruit Tree Collection, Irrigated Agriculture Research and Extension Center, Washington State University, 24106 N. Bunn Road, Prosser, WA 99350 and found to be free of known viruses. Certified virus-indexed propagation material is available from NRSP5. Genetic material of this release will be deposited in the National Plant Germplasm System where it will be available for research purposes, including development and commercialization of new cultivars. It is requested that appropriate recognition be made if this germplasm contributes to the development of a new breeding line or cultivar. The Agricultural Research Service has no plants of 'Galaxy' available for distribution. Limited quantities of budwood may be obtained by writing David W. Ramming, USDA, Agricultural Research Service, 9611 South Riverbend Avenue, Parlier, CA 93648.

\section{Literature Cited}

Bailey, C.H. and L.F. Hough. 1983. Peach tree-N.J. F-2 cultivar. U.S. Plant Patent 5,123.

Mehlenbacher, S.A., L.F. Hough, C.H. Bailey, and J.L. Frecon. 1985. 'Stark ${ }^{R}$ Saturn' Peach. Fruit Var. J. 39:33.

Okie, W.R. 1998. Handbook of peach and nectarine varieties: Performance in the southeastern United States and index of names. UUSDA Hndbk. 714.

Ramming, D.W. and O. Tanner. 1987. 'Mayfire' nectarine. Fruit Var. J. 41:80-81. 